\title{
Should Courts Enforce Credit Contracts Strictly? ${ }^{1}$
}

\author{
Alberto Zazzaro \\ Università Politecnica delle Marche
}

May 15, 2003

\begin{abstract}
${ }^{1}$ Alberto Zazzaro, Università Politecnica delle Marche, Dipartimento di Economia, Piazzale Martelli 8, 60121 - Ancona - Italy; Tel. 0039-071-2207086; Fax. 0039071-2207102; e-mail albertoz@dea.unian.it. A preliminary version of this paper was co-authored by Davide Iacovoni, whose contribution is gratefully acknowledged. The paper has greatly benefited from very helpful comments and suggestions by Antonio Ciccone, David de Meza Alberto Niccoli and an anonymous referee. Helpful discussions with Piero Alessandrini, Maria Rosaria Carillo, Pino Marotta, Luca Papi, Emma Sarno and Domenico Scalera are also gratefully acknowledged. All the opinions and mistakes are, of course, sole responsibility of the author. The research benefited from financial support from the Italian Ministry for Higher Education and Research (MIUR).
\end{abstract}




\begin{abstract}
The linkages between law and finance are currently the centre of wideranging empirical investigations. This article analyse the effects of legal system efficiency on the functioning of the credit market by using a simple banking model with information asymmetries about borrowers' entrepreneurial talent. It is shown that improvements in the enforcement of contracts by courts reduce agency problems, but can also reduce banks' incentive to adequately screen borrowers, thus worsening credit allocation and social welfare. Improvements in accounting standards, however, always make bank screening of borrowers less costly and improve credit allocation.
\end{abstract}

Keywords: Accounting standards, law enforcement, screening, credit allocation.

JEL classification: G21, K41, K42. 


\section{Introduction}

When firms borrow, the lenders are entitled to a flow of payments to be paid in the future as a reward for money lent today. In order for this transaction to be attractive, this entitlement must be adequately protected by law.

The intimate linkages between law and finance are currently the centre of wide-ranging empirical investigations initiated by a series of articles by La Porta, Lopez-de-Silanes, Shleifer and Vishny (henceforth LLSV). They find cross-country evidence that the degree of legal protection of outside investors and the quality of law enforcement affect the functioning of stock markets. In particular, countries whose legal systems strictly protect shareholder rights have large capital markets ${ }^{1}$ (LLSV, 1997), diffuse ownership (LLSV, 1998; Claessens et al. 2000), generous dividend policies (LLSV, 2000), high returns on equity (Lombardo and Pagano, 1999), and high valuations of firms relative to the book value of their assets (La Porta, Shleifer and Silanes, 1999).

Similarly, LLSV (1997) find that the protection of creditor rights is positively correlated with the breadth of the credit market (see also Galindo and Micco, 2001), whereas Gropp, Scholtz and White (1997) show that in US states with debtor-oriented bankruptcy rules credit granted to low-asset households is low and the interest rates charged by banks are high. Others document that credit markets are positively affected by the degree of law enforcement. For instance, Bianco, Jappelli and Pagano (2002) find that the inefficiency of courts in Italy, as measured by the number of pending trials per thousand people and the average length of trials, is positively correlated with credit rationing and is negatively correlated with the volume of lending. Moreover, they find that interest rates charged by banks are high in provinces belonging to judicial districts where processes last longer. Fabbri

\footnotetext{
${ }^{1}$ In terms of the ratio of outsider held stock market capitalization to GNP, the number of domestic listed firms per million people, and IPOs per million people.
} 
and Padula (2001) document that, still in Italy, judicial efficiency also affects the availability of credit to households. Levine $(1998,1999)$ and Beck, Levine and Loayza (1999) find that countries with well-developed banking systems and high rates of economic growth tend to have strict contract enforcement, well protected creditors, and transparent accounting standards ${ }^{2}$.

However, the relationship between the efficiency of legal systems, the degree of protection accorded to investors, and the performance of financial markets is not as clear-cut positive as it may seem at a first sight. For instance, Padilla and Requejo (2001) find that the volume of lending is not statistically correlated with either creditor rights or law enforcement in OECD countries. Furthermore, they observe a positive relationship between interest rates and law enforcement, and more importantly, they do not find any statistically significant correlation between creditor protection and nonperforming loans. Bianco et al. (2001) find, in fixed-effect regressions, that the stock of pending trials is negatively correlated with the interest rates charged by banks and the amount of non-performing loans. Finally, Lucchetti, Papi and Zazzaro (2001), controlling for the cost efficiency of banks, find only a very weak positive correlation (and not always significant) between the efficiency of bankruptcy trials and economic growth.

How is it possible to reconcile these findings? Do they really conflict with each other? In fact, some of the conflicts in the evidence may be only apparent. They may be resolved by taking into account the simple fact that different types of laws affect the credit market in different ways. In this paper we show that laws that govern accounting standards may affect the credit market quite differently from laws that govern the enforcement of contracts. Improving accounting standards (for instance, by tightening accounting rules, reporting rules, sanctions for fraudulent reporting) makes

\footnotetext{
${ }^{2}$ Regarding the effects of the legal and financial systems on the real economy, see also Dermigüç-Kunt and Maksimovic (1998) and Rajan and Zingales (1998).
} 
bank screening more efficient and less costly, and improves the allocation of credit. Improving enforcement standards (such as the efficiency and speed of foreclosure and bankruptcy procedures) reduces agency problems, and thus makes it easier for entrepreneurs to secure external finance. It can, however, also reduce banks' incentive to adequately screen and monitor borrowers, thus worsening credit allocation and social welfare ${ }^{3}$. In other words, banks' protection by law and courts may be a substitute for screening. Consequently, legal system efficiency does not always correlate with efficient credit allocation $^{4}$.

This paper presents a simple competitive banking model with information asymmetries about the entrepreneurial talent of borrowers (i.e., about their probability of success). In order to overcome this information gap, banks may use costly credit-worthiness tests to screen applicants. We assume that the probability of errors in screening applicants is negatively correlated with the amount of resources spent on screening. We also suppose that the marginal cost of screening decreases with the quality and transparency of accounting standards. Instead, courts efficiency and enforcement laws affect the amount of money that banks are able to recover through bankruptcy proceedings in the case of borrowers' failure.

The main results we derive are the following: (i) Both accounting standards and enforcement reforms reduce the interest rate charged by banks; (ii) the amount of information produced by banks and the average number of credit defaults depend on the type of legal reforms: accounting standard reforms reduce screening costs, thereby increasing screening activity, while

\footnotetext{
${ }^{3}$ As Manove, Padilla and Pagano (2001, p. 19) point out, "incentive problems may also arise on the creditor's side".

${ }^{4}$ In this paper for the sake of simplification it is assumed that the two types of legal reforms only have consequences in their respective domain. Assuming otherwise can lead to legal reforms that have non-monotonic effects on the efficiency of credit markets (Iacovoni and Zazzaro, 2000).
} 
enforcement reforms reduce screening benefits, thereby decreasing screening activity; (iii) the effects of legal reforms on the average amount of lending and credit rationing depend on whether the banks' screening technology tends to be conservative or overestimate the entrepreneurial ability of applicants; (iv) accounting reforms are welfare enhancing, whereas stricter contract enforcement by courts may be welfare reducing; (v) banks underinvest resources in screening their applicants with respect to the social optimum.

In the literature, there are contributions where the strict protection of creditor rights has adverse efficiency consequences. For instance, Bebchuk and Fried $(1996,1997)$ maintain that the mandatory full priority to secured debts in bankruptcy may give rise to inefficient creation of security interests, to suboptimal use of covenants, to moral hazard behaviour by borrowers, and to suboptimal enforcement efforts by creditors. Bebchuk and Picker (1998), and Berkovitch, Israel and Zender (1998) argue that strict protection of creditor rights in bankruptcy may reduce the incentive of firm management to invest in its own specific human capital ${ }^{5}$.

However, more relevant to the present paper are the contributions by Manove, Padilla and Pagano (2001), and Bianco et al. (2002).

Manove et al. (2001) present a banking model where banks and firms may use collateral as a substitute for screening. They argue that, when screening costs are sufficiently high, a legal system that facilitates the repossession of collateral creates an incentive to offer loan contracts requiring high collateral and no screening. This incentive moves the equilibrium allocation of credit away from the first best, and increases the average amount of non-performing loans. Their paper, however, differs from ours in many

\footnotetext{
${ }^{5}$ Similar adverse efficiency results are obtained by Burkart and Panunzi (2001) with regard to shareholder rights. Namely, they show that when legal shareholder protection and ownership concentration are substitutes, legal reforms that reinforce shareholders rights may exacerbate the conflict between large and small shareholders, and may induce the former to take diversionary actions.
} 
aspects. First, Manove et al. suppose that entrepreneurs cannot observe the actual quality of their investment project, and consequently that the act of screening is valuable for entrepreneurs too. Secondly, they assume that banks cannot choose the screening intensity, but that screening does reveal the present value of the project selected with certainty. Thirdly, they assume entrepreneurs to be endowed with a positive amount of wealth that can be pledged as collateral to banks.

Bianco et al. (2002) develop a banking model with strategic default where the efficiency of courts in enforcing loan contracts affects the amount of inside and outside collateral that may be recovered. Improvements in court efficiency reduce the minimum collateral requirements by motivating entrepreneurs to repay loans. This reduction, in turn, reduces credit rationing. However, it also permits riskier and less wealthy borrowers to enter the credit market, which may lead to higher interest and default rates. Unlike the present paper, the Bianco et al. model does not take into account ex-ante information asymmetries, and hence, the adverse consequences of the legal reform that they demonstrate are based on composition effects that worsen the average quality of applicants.

The rest of the paper is organized as follows. Section 2 describes the credit-game. Section 3 derives the equilibrium under perfect competition, and considers the effects of legal reforms on credit allocation. Section 4 examines equilibrium under monopoly. Section 5 discusses possible extensions of the model. Section 6 presents the conclusion.

\section{The set-up}

\section{$2.1 \quad$ Agents}

Consider a one-period credit market consisting of many risk-neutral entrepreneurs, each of whom can undertake an investment project, and risk- 
neutral lenders (banks) raising funds at a zero interest rate. Each investment project requires one unit of money. Entrepreneurs have no financial resources of their own, so that one unit of outside finance must be raised to fund the project. Lenders have enough capital to finance the entrepreneurs but they do not share with them the know-how to pursue the investment projects by themselves.

Any investment project generates a random return with two possible outcomes: $Y>1$, in case of success, and $0<y<Y$, in case of failure. The project returns are common knowledge.

Entrepreneurs are of two types: good entrepreneurs whose probability of success is $g$, and bad entrepreneurs for whom the probability of success is $b<g$. Projects run by good entrepreneurs have positive net present value (NPV), while bad entrepreneurs' projects have negative NPV. From a societal point of view, therefore, only good entrepreneurs should be funded. Summarising:

Assumption 1. $N P V_{g}=g Y+(1-g) y>1 ; N P V_{b}=b Y+(1-b) y<1$.

\subsection{Screening Technology}

The proportion of good entrepreneurs with respect to the entire entrepreneur population is $\theta$. Banks know the share of type-g entrepreneurs, but they are unable to distinguish good entrepreneurs from bad ones, and self-selection devices for entrepreneurs are not available. Banks are, however, endowed with a costly screening technology: before granting a loan they may perform a credit-worthiness test resulting in a noisy signal, $S$, of the applicants' ability.

Let us assume that an unscreened project has a negative net present value for banks and loans granted to unscreened projects are not profitable:

Assumption 2. $N P V_{u}=\theta N P V_{g}+(1-\theta) N P V_{b}<1$. 
Therefore, from assumption 2, in order for the credit market to exist, banks must screen applicants. Screening costs increase with the resources $s \in] 0, \infty[$ that the banks employ in evaluating a loan application. However, besides resources spent on checking and evaluating financial statements as well as on gathering extra information on the quality of the applicants' projects, screening costs also depend on the quality and transparency of the accounting standards set by the law.

As mentioned earlier, the efficiency of accounting standards is a highly composite concept which comprises various aspects, such as the commercial law in force, the breadth of general information included in the firms' annual reports, the number and type of book-keeping entries, and the kind of sanctions provided for fraudulent book-keeping by the law. When the quality and transparency of accounting rules are defective, applicants' disclosures are not easily interpretable, and the proper screening of borrowers is a difficult task for banks. In theses cases, evaluating the entrepreneurs' ability becomes highly costly and its outcome quite uncertain ${ }^{6}$.

Formally, let us assume that screening costs are an increasing and linear function of $s$ and that they are a decreasing function of a parameter $\ell_{s} \in[0,1]$ which denotes the quality of the accounting standards:

$$
C_{s}=\beta\left(c-\ell_{s}\right) s
$$

with $\beta>0$ and $c>1$.

The signal obtained by banks from performing a credit-worthiness test can take only two values, i.e., $S=\{G, B\}$. Once the signal is received, banks must decide whether or not to grant the loan; hence the set of feasible actions for a bank is $\Lambda=\{A, D\}$, where $A$ denotes that the application is accepted and loan is granted and $D$ that it is denied.

\footnotetext{
${ }^{6}$ In the following, however, to simplify the analysis, we assume that just screening costs, and not the screening outcome, are affected by the law.
} 
The greater the resources spent by banks on screening, the more accurate the signal becomes, that is, the greater is the probability that a loan will be granted to a good entrepreneur, and the lower the probability that bad projects will be funded. However, the screening effort is not observable by applicants and not verifiable by a court, and hence cannot be part of an enforceable contract.

Let us denote by $\operatorname{Pr}(G \mid g, s)$ the probability that a bank will correctly recognize a good entrepreneur as such when the resources employed in screening loan applications are $s$, and by $\operatorname{Pr}(G \mid b, s)$ the probability that it will erroneously evaluate a bad entrepreneur as a good one. The probability of correctly recognizing a good or a bad entrepreneur increases with $s$. More specifically, selecting an entrepreneur randomly from the population:

$$
\begin{gathered}
\operatorname{Pr}(G \mid g, s)=1-(1-\alpha) e^{-\gamma s} \\
\operatorname{Pr}(G \mid b, s)=\alpha e^{-\gamma s}
\end{gathered}
$$

where $\gamma>0$ is a parameter measuring the information content of $s$, whereas $\alpha \in[0,1]$ denotes the bank's ability to recognize a good entrepreneur (i.e., a higher value of $\alpha$ denotes a higher propensity to make type-II errors and a lower propensity to make type-I errors).

When $s$ tends to zero, the probability of recognizing a good entrepreneur coincides with the probability of not recognizing a bad entrepreneur, that is the signal received by banks is totally uninformative:

$$
\lim _{s \rightarrow 0} \operatorname{Pr}(G \mid g, s)=\lim _{s \rightarrow 0} \operatorname{Pr}(G \mid b, s)=\alpha
$$

By contrast, when banks employ an infinite amount of resources in their screening, the probability of committing type-I or type-II errors vanishes, i.e., the signal received by banks is fully informative:

$$
\lim _{s \rightarrow \infty} \operatorname{Pr}(G \mid g, s)=1 \text { and } \lim _{s \rightarrow \infty} \operatorname{Pr}(G \mid b, s)=0
$$


From (2) and (3), together with the assumption that $\operatorname{Pr}(g)=\theta$, one obtains:

$$
\operatorname{Pr}(G)=\theta-(\theta-\alpha) e^{-\gamma s}
$$

Therefore, if $\alpha>\theta$, the probability of receiving the signal $G$ is always higher than the proportion of type- $g$ entrepreneurs, i.e., $\operatorname{Pr}(G)>\theta, \forall s$. In this case, banks may be said to be incurably optimistic about the entrepreneurial ability of their applicants. If $\alpha<\theta, \operatorname{Pr}(G)<\theta$, whatever the screening effort, banks are incurably pessimistic.

Remark 1 Depending on whether the banks are pessimistic or optimistic, a greater screening effort increases or decreases the probability of receiving the signal $G$, i.e., $\frac{\partial \operatorname{Pr}(G)}{\partial s} \gtrless 0$ iff $\theta \gtrless \alpha$.

\subsection{Bankruptcy Proceedings}

The realization of project returns is observable and costly verifiable. The optimal contract is, therefore, the so-called standard debt contract, which specifies a fixed non-contingent repayment (principal plus interest). When the borrower fails to honour the contract, costly monitoring and bankruptcy procedures ensue, resulting in the seizure of all the borrower's earnings from the project by the lender ${ }^{7}$.

However, because of inefficiency in law enforcement, when the borrower defaults, banks may not be able to extract all the borrower's earnings - ascertained by means of monitoring - to which they are contractually entitled. In fact, the amount of credit recovered by banks depends on the effectiveness of the legal and judicial system in protecting their claims. Where bankruptcy procedures do not enforce creditors' rights adequately, or when courts are inefficient, the debt recovery process may be costly, time-consuming, and highly uncertain in its outcome.

\footnotetext{
${ }^{7}$ The standard references are Townsend (1979), Gale and Hellwig (1985) and Williamson (1987).
} 
From a formal point of view, we assume that for any unit of money ascertained by the auditor, the amount the creditor effectively seizes from the borrower is just $\ell_{m} \in[0,1]$. The remaining $\left(1-\ell_{m}\right)$ consists of judicial costs or resources wasted in bankruptcy procedures ${ }^{8}$.

\subsection{The credit game and the credit market equilibrium}

To sum up the discussion so far, banks and entrepreneurs play the following game:

Time 0: Nature chooses the entrepreneurs' ability and reveals it to them.

Time 1: Banks announce loan interest rates, that can depend on screening outcomes. Each bank acts in the belief that other banks' interest rates and screening effort are constant.

Time 2: Individuals apply for loans. Each of them can apply to only one bank in the period. If the application is rejected, their investment opportunity vanishes.

Time 3: Banks screen loan applications and decide whether or not to satisfy the demand for credit. The banks' screening effort is not observable by borrowers and, therefore, is not contractible.

Time 4: Investment projects generate their returns. In case of failure, banks apply to courts for recovering their credit.

Credit market equilibrium is characterized by: (i) an amount of resources, $s^{*}$, devoted to the screening of loan applications; (ii) a lending rule $\Lambda^{*}=\{\lambda|S=G ; \lambda| S=B\}$, for $\lambda=A, D$; (iii) a gross interest rate $R^{*}$.

\footnotetext{
${ }^{8}$ Another possible interpretation is that the remaining $\left(1-\ell_{m}\right)$ units of money are kept by the borrower, who can therefore take advantage of the structural inefficiency of the legal system. From a formal point of view, this interpretation only entails that, for incentive reasons, the loan interest rate cannot exceeds $\left(1-\ell_{m}\right) Y$.
} 


\section{Equilibrium in a competitive credit market}

Under perfect competition, the equilibrium credit policy maximizes the expected payoff of entrepreneurs subject to the constraint that banks earn zero profits.

As already pointed out, banks need to screen loan applicants and this gives rise to two possible results: the credit-worthiness test is passed or it is failed. Therefore, in principle, two different contracts should be drafted, one for type- $G$ entrepreneurs and the other for type- $B$ entrepreneurs. This eventuality, however, can be excluded by the following proposition.

Proposition 1 If banks devote a positive amount of resources to the screening of loan applicants in equilibrium, the optimal lending rule is $\Lambda^{*}=$ $\{A|S=G, D| S=B\}$. Otherwise, the optimal lending rule is $\Lambda^{* *}=$ $\{D|S=G, D| S=B\}$ and the credit market collapses.

Proof. The proof follows directly from Assumption 2 and from the fact that the screening technology is informative. Applying Bayes' rule to (2) and (3), it is straightforward to verify that $\operatorname{Pr}\left(g \mid B, s^{*}>0\right)<\theta$, and $\operatorname{Pr}(b \mid G$, $\left.s^{*}>0\right)<(1-\theta)$, where $s^{*}$ denotes the optimal screening effort (to be derived below).

Hence the optimal lending rule states that banks should refuse loans to entrepreneurs who have not passed the credit-worthiness test. Moreover, since screening effort is not contractible, the optimal debt contract must be drafted in such a way as to maximize the expected type- $g$ borrowers' payoff. The optimal contract results from the following maximization program:

$$
\max _{R, s} E\left(\pi^{g}\right)=g(Y-R)
$$

s. t. $E\left(\pi^{B}\right)=\operatorname{Pr}(G)\left[\wp R+(1-\wp) \ell_{m} y-1\right]-\beta\left(c-\ell_{s}\right) s=0$ 


$$
R \leq Y
$$

The participation constraint $(\mathrm{PC})$ requires that the interest rate charged by banks allows them to cover all the screening costs, including those incurred for unapproved applications. The feasibility constraint (FC) requires that the contract yields a non-negative return to the borrower. $\wp$ denotes the probability of success of applicants who have passed the credit-worthiness test:

$$
\wp=b+(g-b) \operatorname{Pr}(g \mid G)
$$

Remark $2 \wp$ increases with $s$. If $\alpha \leq 2 \theta, \wp$ is a concave function of $s$.

Proof. From Bayes's rule, $\operatorname{Pr}(g \mid G)=\frac{\theta\left[1-(1-\alpha) e^{-\gamma s}\right]}{\operatorname{Pr}(G)}$, and then $\frac{\partial \operatorname{Pr}(g \mid G)}{\partial s}=$ $\frac{\alpha \gamma \theta(1-\theta) e^{-\gamma s}}{\operatorname{Pr}(G)^{2}}>0$. Differentiating again with respect to $s$ it is straightforward to verify that $\operatorname{sign} \frac{\partial^{2} \operatorname{Pr}(g \mid G)}{\partial s^{2}}=\operatorname{sign}\left[(\alpha-\theta) e^{-\gamma s}-\theta\right]$, which certainly (i.e., $\forall s>0$ ) assumes negative values if $\alpha<2 \theta$.

From the $\mathrm{PC}$, the equilibrium gross interest rate is

$$
R^{*}=\frac{\beta\left(c-\ell_{s}\right) s+\operatorname{Pr}(G)}{\wp \operatorname{Pr}(G)}-\frac{(1-\wp)}{\wp} \ell_{m} y
$$

Because of perfect competition, the optimal screening intensity is given by the value of $s$ that minimizes the equilibrium interest rate $R^{*}$, subject to the feasibility condition $R^{*} \leq Y$. Differentiating (4) with respect to $s$, it can be immediately verified that the optimal screening intensity is implicitly determined by the following expression ${ }^{9}$ :

$$
\beta\left(c-\ell_{s}\right)\left[\wp \operatorname{Pr}(G)-s \frac{\partial \wp}{\partial s} \operatorname{Pr}(G)-s \wp \frac{\partial \operatorname{Pr}(G)}{\partial s}\right]=\frac{\partial \wp}{\partial s} \operatorname{Pr}(G)^{2}\left(1-\ell_{m} y\right)
$$

Given Assumption 2, when $s$ tends to $0, R>Y$. If $\left.\frac{\partial R}{\partial s}\right|_{s=0}<0$, then $s^{*}$ assumes positive values.

\footnotetext{
${ }^{9}$ The second order condition is satisfied by construction.
} 
Proposition 2 Any improvement in the legal system efficiency, either in accounting standards or in bankruptcy procedures, leads to a reduction in the equilibrium interest rate $R^{*}$.

Proof. Differentiating (4) with respect to $\ell_{s}$ and $\ell_{m}$ we have:

$$
\frac{\partial R}{\partial \ell_{s} \mid s=s^{*}}=-\frac{\beta s^{*}}{\wp \operatorname{Pr}(G)} ; \quad \frac{\partial R}{\partial \ell_{m} \mid s=s^{*}}=-\frac{1-\wp}{\wp} y
$$

Under perfect competition, improving the efficiency of the legal system unambiguously reduces the interest rate. The reason is simple. The marginal effect of an improvement in accounting standards and courts efficiency on the optimal screening effort does not affect the equilibrium interest. However, more transparent accounting rules and stricter enforcement of contracts by courts tend to increase banks' profits and lead banks to reduce interest rates.

The effect on screening intensity, and on the efficiency of credit allocation, is however ambiguous. In particular, it depends on the type of legal reform accomplished. Accounting standard reforms reduce marginal screening costs and increase the optimal screening effort. By contrast, enforcement reforms reduce marginal screening benefits and make accurate screening of the applicants less urgent. The benefit accruing to banks from screening is inversely proportional to the amount of borrower's earnings they can seize through bankruptcy procedings. An increase in $\ell_{m}$ reduces judicial costs and raises the amount of loan recovered in case of borrower's default, so that accurate screening of the applicants' entrepreneurial ability becomes relatively less important. These observations motivate the following proposition.

Proposition 3 The optimal screening effort increases with $\ell_{s}$ and decreases with $\ell_{m}$.

Proof. From the envelope theorem $\operatorname{sign} \frac{\partial s^{*}}{\partial \ell_{j}}=-\left.\operatorname{sign} \frac{\partial^{2} R}{\partial s \partial \ell_{j}}\right|_{s=s^{*}}$, for $j=$ $s, m$. By means of equation (5) it is straightforward to verify that $\frac{\partial s^{*}}{\partial \ell_{s}}>0$, and $\frac{\partial s^{*}}{\partial \ell_{m}}<0$. 
The accuracy with which banks screen loan applications affects both the amount of credit granted and the average amount of non-performing loans. More precisely, it is easy to demonstrate the following proposition:

Proposition 4 In equilibrium, if banks are pessimistic (resp., optimistic) about the entrepreneurial ability of their applicants, a greater screening effort implies a higher (resp.,lower) expected rate of credit approvals. The larger the amount of information collected by banks, the smaller the average proportion of defaults on granted loans.

Proof. The first part of Proposition 4 follows directly from Remark 1. As regards the share of expected defaults, it is given by $d^{e}=(1-\wp)$. From Remark 2, therefore, $\frac{\partial d^{e}}{\partial s^{*}}<0$.

Table 1 summarises the results of comparative statics. In competitive credit markets, improvements in law enforcement lead to a reduction in the interest rate, but an increase in the average amount of non-performing loans ${ }^{10}$. Moreover, in the cases where the banks are pessimistic (resp., optimistic), the average number of loan applications' approvals is reduced (resp., increased) and credit rationing increased (resp., diminished). Accounting standard reforms, instead, give rise to a reduction in both interest and expected default rates; where the banks are pessimistic (resp., optimistic), the lending volume is increased (resp., reduced) and credit rationing diminished (resp., increased).

\footnotetext{
${ }^{10}$ These results appear to fit with the evidence by Bianco et al. (2002) quoted in the Introduction, especially concerning the effect of judicial efficiency on the default rate.
} 
Table 1. The effects of legal reforms on competitive credit markets

\begin{tabular}{ccccc}
\hline & \multicolumn{2}{c}{ Accounting standard reforms } & \multicolumn{2}{c}{ Enforcement reforms } \\
\hline & $\alpha>\theta$ & $\alpha<\theta$ & $\alpha>\theta$ & $\alpha<\theta$ \\
\hline Interest rate & - & - & - & - \\
Lending volume & + & - & - & + \\
Credit rationing & - & + & + & - \\
Average default & - & - & + & + \\
\hline
\end{tabular}

\section{Policy and welfare analysis}

This section is devoted to three policy/welfare issues: (i) the allocative efficiency of the competitive solution; (ii) the potential for government intervention and efficient legal reforms; (iii) the comparison between the private incentive to screen applicants and the welfare maximising screening intensity.

\subsection{The allocative efficiency}

The first issue to examine is the allocative efficiency of the competitive solution. From Assumption 1, we know that to implement the social optimal credit allocation, all type- $g$ entrepreneurs - but only they - should be financed. At the first-best, therefore, the volume of loans granted is equal to $\theta N$, where $N$ is the number of applicants, and the expected default rate is equal to $(1-g)$.

Now, compare the first-best solution with the competitive equilibrium. At the competitive equilibrium the average amount of lending granted is $\operatorname{Pr}(G) N$. When banks are optimistic about applicants' quality $(\alpha>\theta)$, it always exceeds the first-best level. By contrast, when banks are pessimistic $(\alpha<\theta)$, the equilibrium lending volume is below the first best. Moreover, in both cases, since banks make mistakes in evaluating the merit of credit of their applicants, some type- $g$ entrepreneurs have their application rejected, 
whereas some type- $b$ entrepreneurs see their application approved. This affects the average rate of non-performing loans which is equal to $(1-\wp)$.

An indicator of the allocative efficiency of the banking system is, therefore, given by $\varphi=\frac{(1-\wp)}{(1-g)}$. The higher the value of $s^{*}$, the fewer the errors committed by the banks, and the closer $\wp$ gets to $g$, and $\varphi$ to 1 . From this, it follows immediately that:

Proposition 5 The legal system that ensures the smallest amount of expected non-performing loans is that characterized by the minimal feasible level of contract enforcement by courts, $R^{*}\left(\underline{\ell_{m}}\right)=Y$, and maximal quality of accounting standards, $\ell_{s}=1$.

Proof. It follows directly from Propositions 3 and 4.

The economic intuition behind Proposition 5 is simple. In markets with significant forms of information asymmetries, the protection afforded by non-market institutions (like the legal system) may in some cases substitute for self-protection mechanisms devised by private individuals and may give rise to perverse effects. In our case, when the credit market is perfectly competitive, legal systems that strictly enforce contracts push the banks to rely on the ex-post seizure of borrowers' earnings and to reduce their screening effort. This reduces the efficiency of the credit market, in the sense that it worsens the allocation of credit and increases the average number of non-performing loans.

\subsection{Accounting and enforcement standards reforms}

The allocative inefficiency of the competitive solution, however, is not enough to ask for government intervention. To ascertain whether or not a legal reform is welfare enhancing, changes in screening and monitoring costs must also be taken into account (de Meza and Webb, 1988). An improvement in the enforcement of contracts by courts, for instance, diminishes both 
screening and monitoring costs. Thus, the saving in screening and monitoring costs may justify, from the societal point of view, the cruder selection and the larger number of non-performing loans determined by the same enforcement reform. In these cases, the optimal social level of enforcement is above the minimal feasible level and may also coincide with the maximal level. On the other hand, in principle one cannot exclude that the cost of the deeper screening following an improvement in the accounting standards compensates the reduction in default and monitoring costs, thereby causing a deterioration in social welfare.

Assume that the policy maker has a utilitarian welfare function (de Meza and Webb, 1999). The socially optimal degree of law enforcement and accounting transparency can be evaluated by solving:

$$
\begin{aligned}
\max _{\ell_{m}, \ell_{s}} S W= & (1-\theta) \operatorname{Pr}(G \mid b) N\left[b Y+(1-b) y-(1-b)\left(1-\ell_{m}\right) y-1\right]+ \\
& \theta \operatorname{Pr}(G \mid g) N\left[g y+(1-g) y-(1-g)\left(1-\ell_{m}\right) y-1\right]-N \beta\left(c-\ell_{s}\right) s
\end{aligned}
$$

Using the Bayes rule and the fact that, from the PC constraint, $(1-\wp) \ell_{m} m-$ $1=\wp R^{*}-\frac{\beta\left(c-\ell_{s}\right) s}{\operatorname{Pr}(G)}$, the social welfare function may be rewritten as $S W=$ $\operatorname{Pr}(G) N \wp\left(y-R^{*}\right)$. Moreover, when banks lending in the market are numerous, it is reasonable to assume that on average their capacity to evaluate applicants' entrepreneurial talent is unbiased. In other words, we can reasonably suppose that on average banks are neither incurably optimistic nor pessimistic (i.e., $\alpha=\theta$ ). In this case, the government maximisation program may be written as:

$$
\max _{\ell_{m}, \ell_{s}} S W=\theta N \wp\left(y-R^{*}\right)
$$

Any legal reform, therefore, affects the social welfare through two channels. First, there is the selection effect, which operates through $\wp$. From Propositions 3 and 4 , this effect is positive in the case of a accounting stan- 
dards reform whereas it is negative in the case of a law enforcement reform. Second, there is the interest rate effect that, from Proposition 2, always affects $S W$ positively. Accordingly, the socially optimal degree of accounting standards is always the maximal feasible. By contrast, it is possible that the socially optimal degree of contract enforcement is an interior value, i.e., $\underline{\ell_{m}}<\ell_{m}^{*}<1$. In other words, it is possible that an increase in the efficiency of bankruptcy proceedings reduces the social welfare. More specifically:

Proposition 6 Any improvement in accounting standards is welfare enhancing. If the marginal social benefit of screening out lower ability borrowers, $\left(Y-R^{*}\right)$, exceeds the sum of screening and monitoring costs, $\frac{\beta\left(c-\ell_{s}\right) s^{*}}{\theta}+$ $\left(1-\ell_{m} y\right)$, then stricter contract enforcement may be welfare reducing.

Proof. The sign of the derivative of social welfare with respect to $\ell_{s}$ is:

$$
\frac{\partial S W}{\partial \ell_{s}}=\theta N\left[\frac{\partial \wp}{\partial s^{*}} \frac{\partial s^{*}}{\partial \ell_{s}}\left(Y-R^{*}\right)-\wp \frac{\partial R}{\partial \ell_{s}} \mid s=s^{*}\right]
$$

From equations (4) and (5), and in the light of Remark 3 and the fact that $\frac{\partial^{2} \wp}{\partial s^{* 2}}=-\gamma \frac{\partial \wp}{\partial s^{*}}$, we have:

$$
\frac{\partial S W}{\partial \ell_{s}}=\theta N\left[\frac{\theta \varphi\left(\wp-s^{*} \frac{\partial \wp}{\partial s^{*}}\right)\left(Y-R^{*}\right)}{\gamma\left[\beta\left(c-\ell_{s}\right) s^{*}+\theta\left(1-\ell_{m} y\right)\right]}+\varphi s^{*}\right]
$$

Given Remark 2, the expression $\wp-s \frac{\partial \wp}{\partial s}$ is increasing with $s$, and in $s=0$ is positive. Therefore, $\frac{\partial S W}{\partial \ell_{s}}>0, \forall \ell_{s} \in[0,1]$.

The derivative of social welfare with respect to $\ell_{s}$ is:

$$
\frac{\partial S W}{\partial \ell_{m}}=\theta N\left[\frac{\partial \wp}{\partial s^{*}} \frac{\partial s^{*}}{\partial \ell_{m}}\left(Y-R^{*}\right)-\wp \frac{\partial R}{\partial \ell_{m} \mid s=s^{*}}\right]
$$

From equations (4) and (5), and in the light of the fact that $\frac{\partial^{2} \wp}{\partial s^{* 2}}=-\gamma \frac{\partial \wp}{\partial s^{*}}$ and $\wp=g-\frac{1}{\gamma} \frac{\partial \wp}{\partial s^{*}}$, we have:

$$
\frac{\partial S W}{\partial \ell_{m}}=\theta N\left[1-g-\frac{1}{\gamma} \frac{\partial \wp}{\partial s^{*}}\left[\frac{\theta\left(Y-R^{*}\right)}{\beta\left(c-\ell_{s}\right) s^{*}+\theta\left(1-\ell_{m} y\right)}-1\right]\right]
$$


Therefore, a necessary condition for having $\frac{\partial S W}{\partial \ell_{m}}<0$ is that $\left(Y-R^{*}\right)>$ $\frac{\beta\left(c-\ell_{s}\right) s^{*}}{\theta}+\left(1-\ell_{m} y\right)$.

The intution behind the adverse effect of better contract enforcement by courts is the following. Under competition, free-entry entails that in equilibrium the bank profits are zero no matter what the borrower pool quality may be. Once confronted with an improvement in courts' efficiency, banks reduce the screening effort and, urged by competition, pass the increase in profitability to their borrowers. This dimininishing of the interest rate increases the expected utility of applicants and social welfare. However, a worse selection of applicants by banks also increases the probability of funding low-quality entrepreneurs and reduces the probability of funding high-quality entrepreneurs. In both cases, this causes a waste of resources from the societal point of view and reduces social welfare.

As the necessary condition stated in Propositition 6 indicates, the adverse welfare effect of enforcement reforms is more likely in economies where the quality of good and bad entrepreneurs is very dissimilar and where the variance of project returns is large. Such extreme distributions of returns are more typical of less developed regions, where many unworthy borrowers may coexist side by side with some able entrepreneur.

Numerical simulations of the relation between social welfare and courts efficiency are reported in Figure $1^{11}$. As one can see, when $Y$ is sufficiently high, $S W$ has a maximum at $\ell_{m}^{*}<1$. The optimal level of enforcement standards is reduced as the quality of accounting standards decreases. By contrast, when $Y$ is lower, the marginal social benefit of screening out good entrepreneurs is small and consequently the adverse selection effect of a bankruptcy proceedings reform is also small. Considering that the implementation of more efficient judicial systems is actually quite a costly under-

\footnotetext{
${ }^{11}$ Numerical simulations were carried out by using Gauss package for Windows NT/95 version 3.2.37.
} 
taking, the cases where stricter enforcement standards reduce social welfare may be more frequent than our model predicts.

[Insert Figure 1 here]

\subsection{Private incentive to screen}

Even when the socially optimal accounting and enforcement standards prevail, the equilibrium screening intensity chosen by banks under perfect competition may in principle be inefficiently high or low.

The socially optimal screening effort, $\widehat{s}$, may be derived from the maximisation of the utilitarian social welfare function defined in (7), not constrained by the competitive behaviour of banks. Focusing on the case in which $\alpha=\theta$, the socially optimal screening effort is:

$$
\widehat{s}=\underset{s}{\arg \max } S W
$$

and is implicitly determined by:

$$
\frac{\partial R}{\partial s}=\frac{\frac{\partial \wp}{\partial s}(Y-R)}{\wp}
$$

Therefore, by inspection of (8) and (5), we can establish the following proposition:

Proposition 7 Under perfect competition, banks systematically underinvest resources in screening their applicants.

Proof. Whatever the value of $\widehat{s}$ is, the right hand side of (8) is positive. Therefore, since $R$ is a convex function of $s$ and gets its minimum at $s^{*}$, it follows that $\widehat{s}>s^{*}$.

The intuition here is that, since entrepreneurs do not have any wealth to invest in the project, banks cannot select applicants by means of the interest rate. Because of competition, therefore, banks set the interest rate 
at the minimum level satisfying the participation constraint, and determine the screening effort accordingly. In other words, competition prevents banks from internalizing the positive selection effect of screening and, consequently, makes the private incentive to screen out bad applicants inefficiently low.

\section{Technological choices, collateral, and long-term credit relationship}

The model that has been presented overlooks aspects that may be important in practice. For this reason the predictive ability of comparative statics drawn from the model must be assessed with caution. Nevertheless, we are fairly confident that the core of the argument advanced by the model resists many possible extensions. This section focuses on three aspects: (i) moral hazard during the life of the investment project; (ii) collateral and the existence of different borrower risk classes; (iii) multi-period bank-firm relationship.

So far it has been assumed that the probability of success of borrowers is exogenously given. In fact, entrepreneurs, facing costly action, can affect the probability of the project succeeding. Suppose, for instance, that entrepreneurs can choose among different technologies with different probabilities of success. Suppose that the technological choice is not verifiable by banks, and hence that loan contracts cannot be made contingent on it. Of course, a less risky technology is valuable for entrepreneurs only if the costs of its adoption are less than its benefits. Therefore, as the loan interest

rate falls, entrepreneurs will employ less risky technologies. This tends to reinforce the negative relationship between the equilibrium interest rate and the efficiency of the legal system. Indeed, given Proposition 2, legal reforms that introduce better-performing judicial institutions or more transparent accounting standards induce banks to lower the interest rate. But this, in 
turn, makes it worth investing in less risky technologies, giving rise to a further reduction in the interest rate.

However, adding technological choice may have ambiguous effect on the optimal level of screening. When good entrepreneurs adopt safer technologies, the marginal benefits deriving from a reduction in the probability of committing type-II errors (that is, granting credit to bad entrepreneurs) increase, whereas the marginal benefits deriving from a reduction in defaults decrease. If the former effect dominates, and if marginal screening costs are low, banks adopt a more severe screening practice. By contrast, if the latter effect dominates, banks reduce the screening effort. In the first case, the existence of interim moral hazard phenomena reduces the substitution effects deriving from an increase in $\ell_{m}$, and increases complementarity effects of an increase in $\ell_{s}$. In the second case, instead, substitution effects tend to be reinforced, and stricter protection of creditors worsens applicants' selection and increases expected defaults even more.

A second aspect not considered by the model is the presence of inside or outside collateral. Indeed, in order to eliminate self-selection devices, that could be a substitute for screening, it has been assumed that entrepreneurs do not have any wealth to invest in the project or to offer as collateral to the banks. However, even though collateral and screening are alternative methods for reducing credit risks, banks usually employ both mechanisms ${ }^{12}$.

Whether the use of collateral tends to increase or decrease in a well functioning legal system is in principle ambiguous, and depends on the par-

\footnotetext{
${ }^{12}$ In Manove et al. (2001) the presence of collateral does not completely offset the screening activity of the banks, even though these remain methods used as alternatives. This is such because they assume that the banks, but not the entrepreneurs, are able to ascertain with certainty the quality of the project undertaken. The entrepreneurs are aware of this: those that have a low probability of selecting a successful project find it advantageous to submit to the banks' screening; those that have a high probability of undertaking a profitable project prefer to provide collateral and save the cost of screening.
} 
ticular economic function collateral has in the loan contract. In competitive credit markets, when collateral serves to recompose divergent opinions between borrowers and lenders about a project's return, the legal reforms that reduce the costs of using or seizing collateral increase the optimal amount of collateral required by banks and decrease the loan interest rate ${ }^{13}$. Vice versa, when collateral is used as a sorting device, legal reforms that lessen the transaction costs of collateral have the effect of reducing the interest rate and the amount of collateral required to separate high-risk borrowers from low-risk borrowers ${ }^{14}$. The same happens when collateral is employed as an incentive device to induce borrowers to repay loans: improvements in courts efficiency and bankruptcy proceedings mitigate moral hazard problems and tend to lower the collateral required by banks and the interest rate $^{15}$. In this case, as shown by de Meza (2001) and Bianco et al. (2001), if creditworthy borrowers differ in their riskiness or wealth, legal reforms may give rise to composition effects, exacerbating the adverse selection effects (or counter-balancing the favourable selection effect due to accounting standard reforms). The reduction in the interest rate charged and the collateral required reduces rationing among borrowers belonging to higher risk or less wealthy classes. As a consequence, the average quality of borrowers worsens and with it the average loan interest rate and the average volume of non-performing loans rise.

Apart from all these effects, enforcement reforms, by strengthening the right to repossess collateral, reduce the banks' incentive to select their borrowers properly. Moreover, in the presence of collateral, accounting standard reforms may also have adverse effects on the screening function of banks. Indeed, transparent accounting rules reduce the cost of screening, but also allow collateral to be evaluated more precisely (Triantis, 1992). This may

\footnotetext{
${ }^{13}$ See Chan and Kanatas (1985), Proposition 2.

${ }^{14}$ See Besanko and Thakor (1987), Proposition 2.

${ }^{15}$ See Bester (1994), Proposition 3, and Bianco et al. (2001).
} 
lower the cost of subscribing secured debt with respect to screened loan contracts and, consequently, reduce the number of screened loans.

Finally, the setting of the model presented in this paper is static. In this context, banks' monitoring activity is limited to verifying investment revenues. In practice, bank-firm relationship continues in time and the monitoring of borrowers can provide banks with signals that help to assess their quality. In these cases, accounting standard reforms facilitate the monitoring and drive banks to employ more resources in information production. Vice versa, just as in the static case, improvements in the efficiency of bankruptcy proceedings induce banks to substitute the control of borrowers for the ex post seizure of borrowers' earnings, reducing incentives to restructure debts and increasing the number of inefficient liquidations of firms (Gertner and Scharfstein, 1991; Bolton and Scharfstein, 1996).

\section{Conclusions}

This article analyses the effects of legal system efficiency on the functioning of the credit market by presenting a simple banking model with information asymmetries about borrowers' entrepreneurial talent. We distinguish between two types of legal reforms: (a) accounting standards reforms and (b) enforcement reforms. The model shows that those reforms that increase the amount and improve the reliability of public information about borrowers (i.e., accounting standards reforms), always improve the credit allocation and the social welfare. Reforms that increase the enforcement of contracts, improve bankruptcy proceedings, and make courts function more efficiently (i.e., enforcement standards reforms), however, may create adverse efficiency and welfare effects. In particular, under perfect competition, the easier it is for banks to recover their debt through bankruptcy, the less important it is for them to properly select borrowers. So, if the marginal social benefit of screening out lower ability borrowers is sufficiently higher than screening and 
monitoring costs, then stricter law enforcement may be counter productive, worsening banks' credit allocation and reducing social welfare. 


\section{References}

[1] Bebchuk, L.A. and Fried, J.M. (1996), "The Uneasy Case for the Priority of Secured Claims in Bankruptcy", The Yale Law Journal, Vol. 105, pp. 857-934.

[2] Bebchuk, L.A. and Fried, J.M. (1997), "The Uneasy Case for the Priority of Secured Claims in Bankruptcy: Further Thoughts and Reply to Critics", Harvard Law School, Discussion Paper, No. 224, University of Harvard.

[3] Bebchuk, L.A. and Picker, R.C. (1998), "Bankruptcy Rules, Managerial Entrenchment, and Firm-Specific Human Capital", Journal of Law and Economics, forthcoming.

[4] Beck, T., Levine, R. and Loayza, N. (2000), "Finance and The Sources of Growth", Journal of Financial Economics, Vol. 58, pp. 195-209.

[5] Berkovitch, E., Israel, R., Zender, J.F.(1998), "Optimal Bankruptcy Law and Firm-Specific Investments", European Economic Review, Vol. 41, pp. 487-97.

[6] Besanko, D. and Thakor A.V. (1987), "Collateral and Rationing: Sorting Equilibria in Monopolistic and Competitive Markets", International Economic Review, Vol. 28, pp. 671-89.

[7] Bianco, M., Jappelli, T. and Pagano, M. (2002), "Courts and Banks: Effects of Judicial Enforcement on Credit Markets", Discussion Paper, No. 3347, CEPR.

[8] Bolton, P. and Scharfstein, D.S. (1996), "Optimal Debt Structure with Multiple Creditors", Journal of Political Economy, Vol. 104, pp. 1-26. 
[9] Burkart, M. and Panunzi, F. (2001), "Agency Conflicts, Ownership Concentration and Legal Shareholder Protection", FMG Discussion Paper, No. 378, London School of Economics.

[10] Chan, Y.-S., and Kanatas, G. (1985), "Asymmetric Valuations and the Role of Collateral in Loan Agreements", Journal of Money Credit and Banking, Vol. 17, pp. 84-95.

[11] Claessens, S. Djankov, S., Fan, J., Lang, L. (2000), "The Separation of Ownership and Control in East Asian Corporations", Journal of Financial Economics, Vol. 58, pp. 81-112.

[12] de Meza, D. (2002), "Overlending?", The Economic Journal, Vol. 112, pp. F17-F31.

[13] de Meza, D. and Webb, D.C. (1988), "Credit Market Efficiency and Tax Policy in the Presence of Screening Costs", Journal of Public Economics, Vol. 36, pp. 1-22.

[14] de Meza, D. and Webb, D.C. (1999), "Wealth, Enterprise and Credit Policy", The Economic Journal, Vol. 109, pp. 153-63.

[15] Dermigüç-Kunt, A., Maksimovic (1998) "Law, Finance, and Firm Growth", The Journal of Finance, Vol. 53, pp. 2107-137.

[16] Fabbri, D. and Padula, M. (2001), "Judicial Costs and Household Debt", CSEF Working Paper, No. 58, Università di Salerno.

[17] Gale, D. and Hellwig, M. (1985), "Incentive-Compatible Debt Contracts: The One Period Problem", Review of Economic Studies, Vol. 52, pp. 647-63.

[18] Galindo, A and Micco, A. (2001), "Creditor Protection and Financial Cycles", Inter-American Development Bank Working Paper, No. 443. 
[19] Gertner, R. and Scharfstein, D.S. (1991), "A Theory of Workouts and the Effects of Reorganization Law", The Journal of Finance, Vol. 46, pp. 1189-222.

[20] Gropp, R., Scholz, J.K. and White, M.J. (1997), "Personal Bankruptcy and Credit Supply and Demand", The Quarterly Journal of Economics, Vol. 112, pp. 217-51.

[21] Iacovoni, D. and Zazzaro, A. (2000), "Legal System Efficiency, Information Production, and Technological Choice: A Banking Model", Quaderni di Ricerca, No. 129, Università di Ancona.

[22] La Porta, R., Lopez-de-Silanes, F., Shleifer, A. and Vishny, R.W. (1997), "Legal Determinants of External Finance", The Journal of Finance, Vol. 52, pp. 1131-50.

[23] La Porta, R., Lopez-de-Silanes, F., Shleifer, A. and Vishny, R.W. (1998), "Law and Finance", Journal of Political Economy, Vol. 106, pp. 1113-55.

[24] La Porta R., Lopez-de-Silanes, F., Shleifer, A. and Vishny, R.W. (2000), "Investor protection and corporate govenance", Journal of Financial Economics, Vol. 58, pp. 3-27.

[25] La Porta, R., Lopez-de-Silanes, F., Shleifer, A. (1999), "Investor Protection: Origins, Consequences, Reform", NBER Working Paper, No. 7428 .

[26] Levine, R. (1998), "The Legal Environment, Banks, and Long-Run Economic Growth", Journal of Money, Credit, and Banking, vol. 30, Part 2, pp. 596-613.

[27] Levine, R. (1999), "Law, Finance, and Economic Growth", Journal of Financial Intermediation, Vol. 8, pp. 8-35. 
[28] Lombardo, D. and Pagano, M. (1999), "Legal Determinants of the Return on Equity", CEPR Discussion Paper, No. 2282.

[29] Lucchetti, R., Papi, L. and Zazzaro, A. (2001), "Banks' Inefficiency and Economic Growth: A Micro-Macro Approach", Scottish Journal of Political Economy, Vol. 48, pp. 400-424.

[30] Manove, M., Padilla, A.J., Pagano, M. (2001), "Collateral vs. Project Screening: A Model of Lazy Banks", RAND Journal of Economics, vol. 32 , pp. $726-44$.

[31] Padilla, A.J. and Requejo, A. (2001), "The Cost and Benefits of the Strict Protection of Creditor Rights", in Marco Pagano (ed.), Defusing Default: Incentives and Institutions, Washington: John Hopkins University Press.

[32] Rajan, R.R. and Zingales, L. (1998), "Financial Dependence and Growth", The American Economic Review, Vol. 88, pp. 559-86.

[33] Townsend, R.M. (1979), "Optimal Contracts and Competitive Markets with Costly State Verification", Journal of Economic Theory, Vol. 21, pp. 265-93.

[34] Townsend, R.M. (1988), "Information Constrained Insurance: The Revelation Principle Extended", Journal of Monetary Economics, Vol. 21, pp. 411-50.

[35] Triantis, G.G. (1992), "Secured Debt Under Conditions of Imperfect Information", Journal of Legal Studies, Vol. 21, pp. 225-58.

[36] Williamson, S.D. (1987), "Costly Monitoring, Loan Contracts, and Equilibrium Credit Rationing", The Quarterly Journal of Economics, Vol. 102, pp. 135-45. 

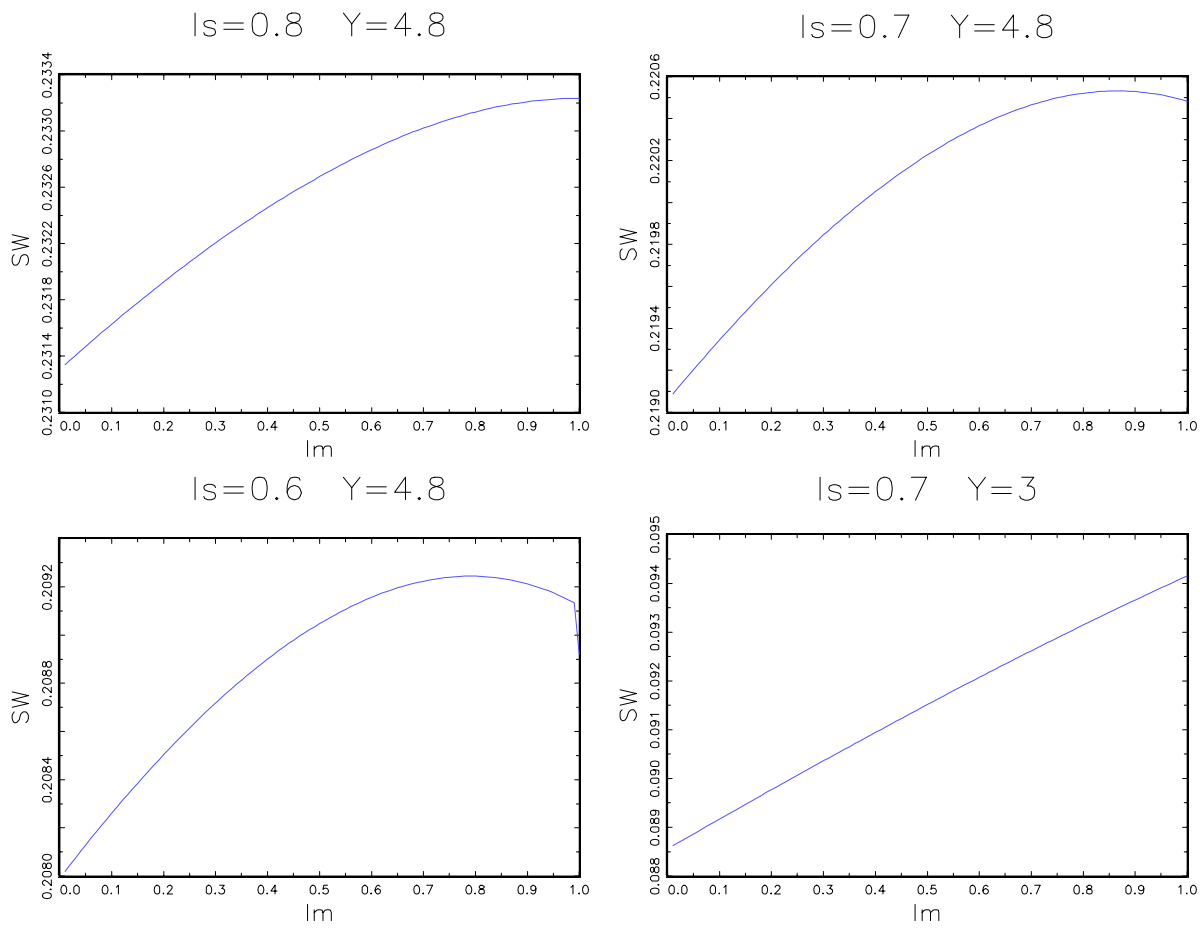

Figure 1: Enforcement reforms and social welfare

$N=1 ; g=0.8 ; b=0.07 ; \theta=0.1 ; \gamma=0.3 ; c=1.1 ; \varphi=0.01 ;$ $y=0.3$ 